\title{
ADGRG1 Gene
}

National Cancer Institute

\section{Source}

National Cancer Institute. ADGRG1 Gene. NCI Thesaurus. Code C99657.

This gene is involved in both brain development and signaling. 